\title{
Synthesis, Investigation and Use Aqueous Acrylic Dispersions
}

\author{
Vladyslav Voloshynets \\ Lviv Polytechnic National University, Lviv, Ukraine \\ Email: vladyslav.voloshynets@gmail.com
}

Received 21 January 2016; accepted 11 April 2016; published 14 April 2016

Copyright (C) 2016 by author and Scientific Research Publishing Inc.

This work is licensed under the Creative Commons Attribution International License (CC BY). http://creativecommons.org/licenses/by/4.0/

c) (†) Open Access

\begin{abstract}
Emulsive polymerization of mono- and dy(meth)acrylates of butandiol, decid(meth)acrylate, methyl- $\alpha$-alkilacrylates with industrial acrylic monomers-butylacrylate, methylacrylate, methacrylic acid, methyl(meth)acrylate has been investigated. Structurization of copolymers using dy(meth)acrylates of butandiol, braking of emulsive polymerization using water insoluble biocides, dy(meth)acrylates of butandiol and methyl- $\alpha$-alkilacrylates have been determined. The mechanism of emulsive polymerization of (meth)acrylic monomers using methyl- $\alpha$-alkilacrylates has been investigated.
\end{abstract}

\section{Keywords}

Emulsive Polymerization, (Meth)acrylates, Biocides

\section{Introduction}

Emulsion polymerization was developed at the end of XIX century as an attempt of reproduction of a polymer discovered in rubber-bearing plants [1]. Nowadays polymerization in emulsion is one of the widespread ways of polymerization used for receiving of synthetic rubbers, acrylic dispersions, polysterene, ABS-plastics, PVA dispersions. As a result of this process a synthetic latex (polymers dispersion) which is directly used in rubber, leather and building industry or is processed in rubber with the help of coagulation and solid polymer secretion is received.

Emulsion polymerization is characterized by a comparatively easy process managing which is caused by good heat exchange conditions and thus by the opportunity of keeping of necessary temperature conditions in all points of a system, as well as the opportunity of adding various additives which influence the polymer qualities during polymerization.

All enumerated peculiarities and advantages of emulsion polymerization, relatively narrow the temperature 
range of its realization [2], accessibility of laboratory equipment induced the investigation of emulsion polymerization on the base of methacrylic monomers.

\section{Discussion}

The investigations have been carried out in following directions:

- the influence of monomeric structure and organic additives on polymerization kinetics and properties of dispersions and copolymers formed from them have been studied

- the formation of a double electric layer and solvation shells around polymeric particles has been studied

- the influence of the disperse environment structure on properties of dispersions and copolymers formed from them has been studied.

With the application of various modified monomers - unsaturated acids [3], mono- and dimethacrylate of diatomic alcohols [4] [5], decylmethacrylates [6] [7], methyl- $\alpha$-alkyl acrylates [8] the kinetics and mechanisms of emulsion polymerization have been investigated, the dispersions on the basis of basic industrial methacrylic monomers (butylacrylate, metylacrylate, metylmethacrylate) have been synthesized, their colloidal chemical properties and film-forming ability have been investigated. The investigation of emulsion polymerization of methyl- $\alpha$-acrylates with a number of acrylic monomers allowed specification of the mechanism of emulsion aqueous polymerization of (meth)acrylic monomers [9]. The destructive influence of decylmethacrylates on emulsion polymerization of methyl acrylates and restriction of their content in monomeric mixture (25\% mas.) have been determined [6] [10]. Up to 25\% increase of decylmethacrylate a monomeric mixture proportionally reduces the rate emulsion copolymerization of methyl acrylate and maximum conversion (Figure 1).

The dispersions of comb copolymers of methyl acrylates with a decylmethacrylates content of $25 \%$ (by weight) in the monomer mixture have been received by emulsion polymerization and their colloidal chemical properties have been investigated [11].<smiles>[R]C(=CC=C(C)C(=O)OC(C)C)C(=O)OCCCCCO</smiles>

$\mathrm{n}=10,12-14 \quad \mathrm{R}=\mathrm{C}_{2} \mathrm{H}_{5}, \mathrm{C}_{3} \mathrm{H}_{7}, \mathrm{C}_{4} \mathrm{H}_{9}$

Within many years a number of different actions including applied character have been done concerning the investigation of application of low-molecular organic additives for giving special properties to the dispersions and films received from them [12].

It has been determined that hard phase low-molecular organic additives such as thiolsulfonate, derivatives of naphthoquinones and dyes lessen the speed of emulsion polymerization and maximal conversion (Figure 2). By this effect they are similar to the action of decyl(meth)acrylate which testifies the similarity of inhibit action in both cases. Both decyl(meth)acrylates and derivatives of naphthoquinones and dyes are water-insoluble, which are distributed in a monomeric phase. One can assume that they block the penetration of radicals from the water 


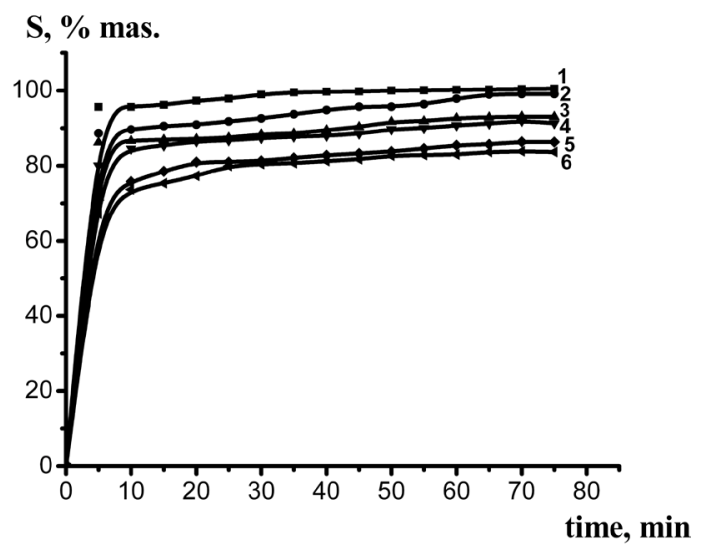

Figure 1. Kinetic curves emulsion polymerization MA for different content: decyl methacrylates in monomer mixture $\left(70^{\circ} \mathrm{C}\right)$, mas. $\%: 1-5$, $2-10,3-15,4-20,5-25$ (For the abstract of the dissertation Kovalenko T.P. Synthesis and properties of comb-like polymers on the basis of decyl(meth)acrylates, Lviv, 2008).

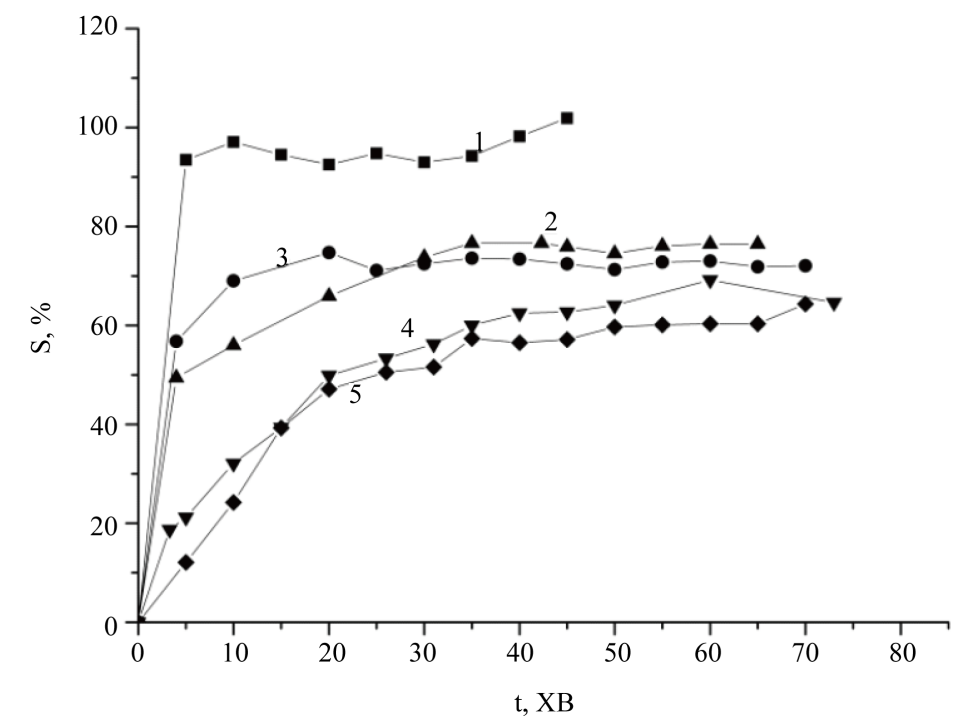

Figure 2. Conversive curves of emulsion polymerization of monomeric mixtures: 1-BA-MA; 2-BA-MA; 3-BA-MA-MAC; 4-BA-MA-MAC in the presence of naphthoquinone, 5-BA-MA-MAC-monomeric azo die (according to the author's abstract DPhil data, Kyiv, 2008)).

phase, namely persulphate ion radicals and hydroxil radicals in the inner part of micelle.

The use of unsaturated acids, monomethacrylates of diatomic alcohols as the most popular methacrylate monomers able to be re-distributed between aqueous and monomeric phases [3] [13] allowed attraction of them, together with emulsifying agents, to formation of protective layers on the surface of polymer particles (Figure 3).

The regulation of $p H$ synthesized dispersions of carboxyl containing polymers allowed essential influence on the structure of a double electric layer and as a result on the value of solvate coverings and globular structure of macromolecules in the disperse phase particles.

$$
\begin{gathered}
\left\{[m(M A-B A-M A C)] n R \mathrm{SO}_{3}^{-}(n-x) X^{+}\right\}^{x-} x X^{+} \\
\left\{[m(M A-B A-M A C)] n\left(B A-M A-C O O^{-}\right)(n-x) X^{+}\right\}^{x-} x X^{+}
\end{gathered}
$$




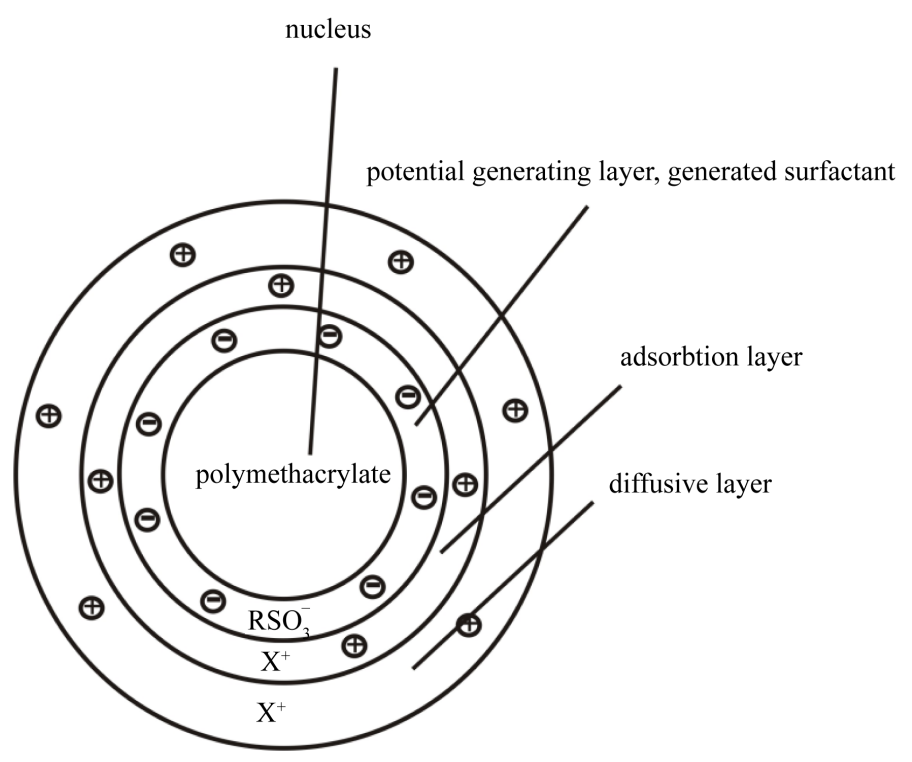

Figure 3. The structure of polymethacrylate aqueous dispersion particle stabilized by anionic surfactant.

$$
X^{+}-H^{+}, \mathrm{Li}^{+}, \mathrm{K}^{+}, \mathrm{Na}^{+},\left[\mathrm{HN}\left(\mathrm{CH}_{2} \mathrm{CH}_{2} \mathrm{OH}\right)_{3}\right]^{+},\left[\mathrm{HN}\left(\mathrm{CH}_{2} \mathrm{CH}_{2}\right)_{2} \mathrm{O}\right]^{+}
$$

The observed essential increasing of stableness of investigated colloidal systems has become the base of technology of frost-resistant acrylic dispersions synthesis development using the technology of non-coagulum polymerization realized in industrial conditions at manufacturing of Ivano-Frankivsk firm "Barva" (Ukraine) [14]. The application of extraction of organic solvents from synthesized dispersions of (alkyl)acrylic monomers proved the high degree of transformation of monomers into a polymer which ensured non-toxicity and ecological compatibility of these colloidal systems [15].

The reconstruction of macromolecules structure in polymeric particles at $p H$ change the consequence of which was the viscosity of dispersions of carboxyl containing polymers (Figure 4) change allowed the essential influence on their interaction with organic additions the molecules of which contained considerable hydrophobic particles [3] [16]. It enabled the regulation of distribution of non-water-soluble organic additions in dispersions and films and their optic properties.

The use of monoatomic alcohols for disperse environment properties regulation allowed the essential influence on rheological properties of dispersions and physical mechanical properties of films received from them without copolymers composition change (Figure 5) [17].

The regulation of $\mathrm{pH}$ of aqueous dispersions of methacrylic polymers and the application of monoatomic alcohols allowed receiving of the homogeneous coverings and films with water insoluble organic additions without their chemical modification. It guaranteed the receiving of coloured and biocidal films with the application of naphthoquinones and thiolsulfonate derivatives.

\section{Practical Use}

The conducted investigations allowed development of the effective film creating compositions which were synthesized at research manufactures of Ukraine and Russia.

Acrylic dispersions synthesized at open joint stock company "Barva" in 1996 were successfully used and are being used for architectural monuments surface purification during restoration in Lviv [18]-[20].

According to the spectrophotometric analysis the amount of particles in these dispersions exceeds $200 \mathrm{~nm}$, which is more than in 1996 and testifies the partial flocculation and agglomeration of particles, but dispersion keeps all main characteristics typical for these materials-typical look, ability to filmmaking, combining at certain $p H$ with organic additives. 


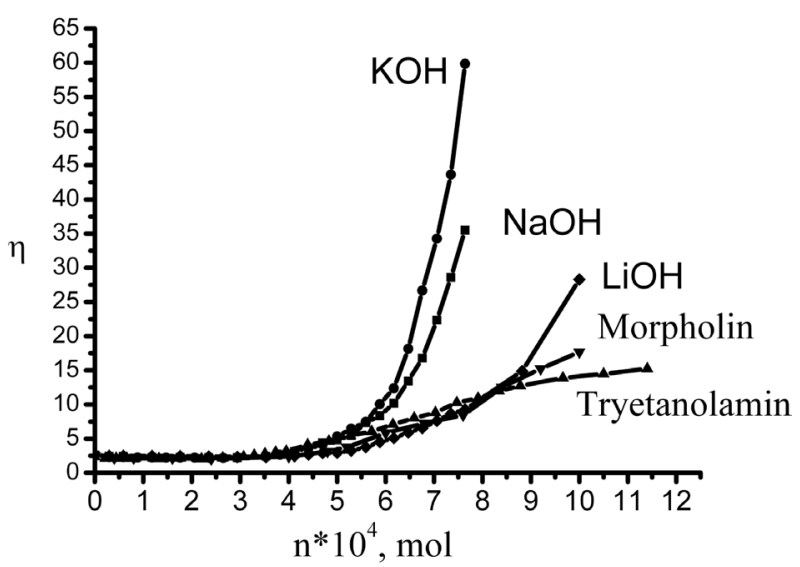

Figure 4. Dependence of relative viscosity of the dispersion BA-MAMAC on the amount of the added bases (mole/ $10 \mathrm{ml}$ of dispersion). Solid residue of dispersion is $40 \%$, temperature is $25^{\circ} \mathrm{C}$. Concentration of the base water solution $0.37 \mathrm{~mol} / \mathrm{l}$ (according to the author's abstract DPhil data, Kyiv, 2008).

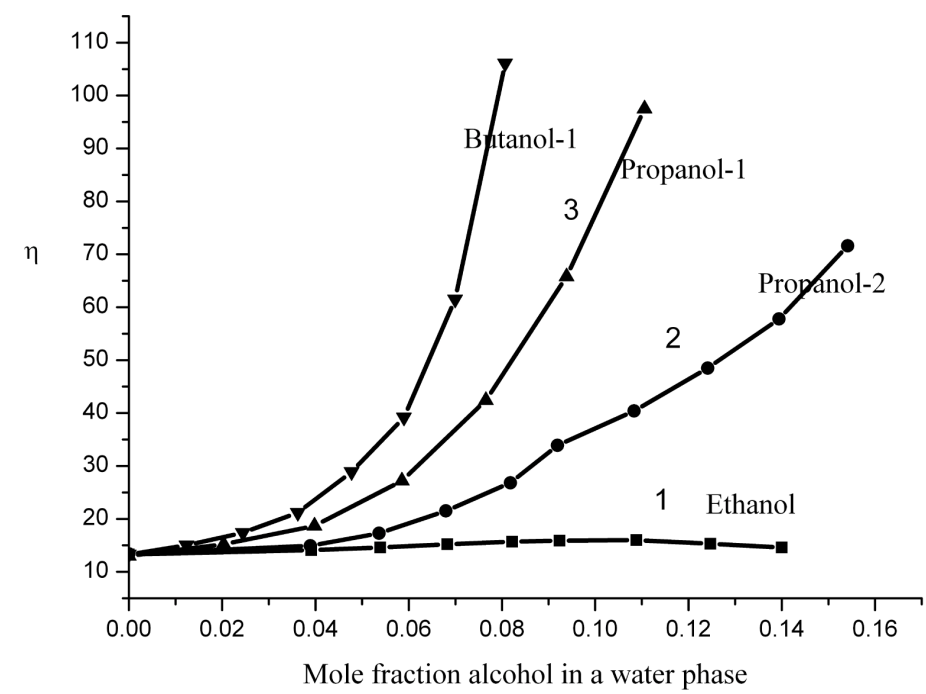

Figure 5. Dependence of relative viscosity of dispersion copolymer butylacrylate-methylacrylate-methacrylic acid (BA-MA-MAC) on the content of alcohol in the system using data from work [17].

\section{Conclusion}

The influence of structure of methacrylic monomers such as monomethacrylates of butandiol, methacrylic acid, decilmethacrylates, methyl- $\alpha$-alkilacrylates on kinetics of emulsive copolymerization and properties of dispersions and films received from them have been determined. During emulsive copolymerization monomethacrylates of butandiol and methacrylic acid are partially re-distributed into a water phase taking part in forming a double electric layer on particles surface. Water insoluble decilmethacrylates, thiolsulfonates, derivatives of naphthoquinones and dyes decelerate the radical emulsive polymerization diminishing the maximum conversion. The regulation of $\mathrm{pH}$ dispersions of methacrylic polymers containing parts of methacrylic acid and the nature of water soluble base influence the viscosity and respectively the hydrodynamic radius of particles. It is conditioned by the structural reconstruction of macromolecules at $\mathrm{pH}$ dispersions change. The structure and content of mono atomic alcohols at certain $\mathrm{pH}$ also influence the structural reconstructure of macro molecules as a result of the interaction with hydrophobic particles of molecules and this changes the viscosity of dispersions. The application of water soluble bases and mono atomic alcohols allowed the influence on distribution of water insoluble 
additives in dispersions and receiving of homogeneous films and coverings. The received results on studying of kinetics of emulsive polymerization of methacrylic monomers with methacrylic acid, receiving and properties of dispersions, films and coverings have become the basis of non coagulum technologies of frost-resistant acrylic dispersions receiving.

\section{References}

[1] Nyzhnyk, V.V., Voloshynets, V.A. and Yuchymenko, N.M. (2010) Polymerization in Homo- and Heterogeneous Systems and the Properties of Polymers Solutions. Kyiv, 254 p.

[2] Baneriee, M., Sathpathy, U., Paul, T.K. and Konar, R.S. (1981) Mechansm of the Emulsion Polymerization of Methyl Methacrylate. Polymer, 22, 1729-1736.

[3] Volosynets, V.A., Van-Chin-Sian, Yu.Ya. and Ganisnyuk, T.A. (2006) Strukturni peretvorennja dyspersij kopolimeriv butylakrylatu-metylakrylatu-metakrylovoi’ kysloty. Polimernyj Journal, 4, 328-335.

[4] Volohinets, V.A., Zaporozsets, T.Yu., Marshalok, G.O. and Semenyuk, I.V. (2000) Svojstva jemul'sionnyh plenok, modificirovannyh mono-i dimetakrilatom butandiola. Plasticheskie Massy, No. 7, 17-19.

[5] Volosynets, V.A., Zaporozsets, T.Yu., Sobechko, I.B. and Semenyuk, I.V. (2000) Vlastyvosti emul’sijnyh spivpolimernyh plivok na osnovi metylakrylatu ta mono- i dyakrylatu butandiolu. Visnyk National university "Lvivska polytechnica”, №. 414, 89-92.

[6] Volohinets, V.A. and Kovalenko, T.P. (2008) Sintez i svojstva jemul'sionnyh sopolimerov metilakrilata s decilmet- i decilakrilatom. Plasticheskie Massy, №. 3, 19-22.

[7] Volohinets, V.A., Kovalenko, T.P. and Visnyk, N.U. (2009) Syntez ta doslidzhennja fizyko-himichnyh vlastyvostej (ko)polimeriv decyl(met)akrylata zi styrolom. Lvivska Polytechnic, №. 644, 53-57.

[8] Volosynets, V.A. and Marshalok, O.I. (2006) Syntez ta doslidzhennja emul'sijnyh kopolimeriv metylakrylatu z metyletakrylatom. Voprosy chimii i chimicheskoj technologii, №. 5, 134-137.

[9] Marshalok, O.I. and Volosynets, V.A. (2007) Abstract 11 Scientific Conf. “Lvivskichim. Chyt” (Lviv Chemical Reading) , Lviv, Ф3.

[10] Volohynets, V.A. and Kovalenko, T.P. (2007) Syntez emul'sijnyh grebnepodibnyh kopolimeriv ta doslidzhennja i’h koloi’dno-himichnyh vlastyvostej. Visnyk National university “Lvivska polytechnica”. № 590, 55-57.

[11] Kovalenko, T.P. and Volohynets, V.A. (2008) Abstract. XV International Conference of Students, Graduate Students and Young Scientists on Fundamental Sciences “Lomonosov 2008”, Lomonosov Moscow State University, Moskow, 8-11 April 2008, 145.

[12] Volohinets, V.A. and Dovbush, M.I. (1991) Abstract. Conference of Young Scientists, Donetsk, 44.

[13] Volosynets, V.A. and Marshalok, O.I. (2010) Abstract. International Conference on the Extraction of Organic Compounds, Voronezh, 20-24 September 2010, 31.

[14] Voloshynets, V., Lytvyn, B., Sokolyck, V. and Parfenov, M. (1997) Materials of Conference “Lvivski chimichnichytannja” [Lviv Chemical Reading], Lviv, 160.

[15] Marshalok, O.I., Voloshynets, V.A. and Polyuzhyn, I.P. (2008) Packing GLC for Determination of Residual Monomers in $\alpha$-Alkyl-Acrylates Dispersions. Polish Journal of Chemistry, 82, 425-430.

[16] Volosynets, V.A. and Panchenko, Y.V. (2013) Abstract. I International Scientific-Practical Conference, Shelkino, 10-13 June 2013, 123.

[17] Voloshinets, V.A., Van-Chin-Sian, Y.Y., Panchenko, Y.V., Pilipenko, A.P. and Yashenko, A. (2006) Vlijanie odnoatomnyh spirtov na kolloidno-himicheskie svojstva akrilatnyh lateksov i na svojstva ih plenok. Plasticheskie Massy, No. 4, 7-10.

[18] Voloshynets, V.A. (2009) Regulation of Adgesion and Cohesive Strength Film Coating for Cleaning of Surfaces. 8th International Conference “Advances in Polymer Technology”, Katowice, 2-5 November 2009, 13.

[19] Voloshynets, V.A. and Bevz, M.V. (2007) Sposib ochyshhennja pam’jatok arhitektury ta mystectva. Ukraine Patent No. 22684.

[20] Voloshynets, V. (2014) Metody fizychne w badaniach I konserwacii zabytkow architektury I dziel sztuki. Raportna Seminarium I naukowym polsko-ukrainskym, 30 kwietnia 2014, Lviv-Warszawa-Celestynow. 